\title{
'n Kritiese besinning oor die plek en samehang van die teologiese vakke in die Fakulteit Teologie van die Nederduitsch Hervormde Kerk van Afrika*
}

\author{
DJ Smith
}

\section{INLEIDING}

Hierdie studiestuk het ten doel om die hele opset van die plek en samehang van die teologiese vakke in afdeling A van die teologiese fakulteit van die Universiteit van Pretoria op so ' $n$ manier in oënskou te neem dat dit tot nadenke stem en tot ' $n$ kritiese gesprek oor die hele opset prikkel. Dit kom met ander woorde daarop neer dat ons nie maar sommer die huidige indeling en samehang tussen die vakke aan ons fakulteit as vanselfsprekend sal aanvaar nie, maar dat ons 'n oog daarvoor sal kry dat daar ook ander maniere is om die teologie ensiklopedies te verdeel, en veral dat dit dan moontlikhede inhou om die teologiese vakke anders en ook moontlik meer vrugbaar aan te bied. Ons wil dan ook die klem daarop lê dat die teologiese vakke so vrugbaar moontlik moet saamhang en aangebied word.

Ons wil ook nie die historiese ontwikkeling van die ensiklopediese indeling van die teologie nagaan wat tot die huidige indeling by ons gelei het nie, maar eerder vanuit die huidige stand van sake en indeling aan ons fakulteit sekere kritiese vrae vra na die korrektheid, verantwoordbaarheid en vrugbaarheid.

In die opskrif het ons gestel dat dit gaan oor die plek en samehang van die teologiese vakke. Hieroor wil ons net enkele opmerkings maak. Wat die plek van die teologiese vakke betref, wil ons nie net vra waar behoort 'n vak te staan nie, maar wil ons ook die moontlikheid van nuwe vakke in die gesigsveld bring, soos bv Ekumeniese

\footnotetext{
*'n Verwerking van 'n referaat gelewer voor die Hervormde Teologiese Vereniging se vergadering van 1980 .
} 
Teologie, of ook die moontlikheid dat vakke wat nou nie ' $n$ afsonderlike plek beklee nie, wel 'n afsonderlike plek gegee kan word, bv die Hermeneutiek. Wat die samehang betref, wil ons nie net vra na die onderlinge verband en die grense tussen die verskillende vakke nie, maar wil ons ook die vraag vra of tussen-dissiplinêre samewerking tot sy reg kom in ons fakulteit.

Word die klem nie dalk te veel gelê op die verskillende vakke in hulle afgeslotenheid nie? Word die vakke nie dalk in isolasie beoefen nie? Is daar genoegsame onderlinge skakeling en oordrag van vakkennis? Kom daar genoeg van die gedagte dat die kerk se teologiese arbeid en spreke tog uiteindelik een groot geheel vorm?

Wanneer ons oor 'n onderwerp soos dié praat, is dit altyd nodig om in gedagte te hou dat die teologie oorspronklik nie in verskillende vakgebiede ingedeel was nie. Aanvanklik was 'n teoloog iemand wat hom besig gehou het met alle aspekte van die teologiese kennis. Dit het wel gebeur dat sekere teoloë hulle meer diepgaande besig gehou het met spesifieke aspekte van teologiese kennis, maar ons het nog geen vakwetenskaplikes gevind nie. Dit is eers vanaf die einde van die sewentiende eeu dat ons'n al groter wordende spesialisie begin kry en dat die verskillende onderafdelings van die teologie begin ontwikkel het tot selfstandige vakke. Die ontwikkeling het deurgegaan tot in ons eeu en ons kan selfs redeneer oor die vraag of die ontwikkeling en totstandkoming van nuwe vakgebiede nie nog voortgaan nie. Dit is in elk geval so dat die bepaling van die ensiklopediese plek van betreklike jong vakgebiede nog redelik vloeibaar is, bv die Godsdienswetenskap, of dat die onderverdeling van so 'n jong vakgebied nog 'n redelike mate van vloeibaarheid het, bv Praktiese Teologie. Dit staan wel vas dat die ontwikkeling so ver gegaan het dat ons kan redeneer oor die vraag of ons nie dalk 'n tyd van oorspesialisering betree wat so toegespits is dat dit ons blik vir die breë verbande in die teologie afstomp nie.

\section{KRITIESE OPMERKINGS OOR DIE VERSKILLENDE VAKGEBIEDE}

\subsection{Ou-Testamentiese en Nuwe-Testamentiese Wetenskap - die Hermeneutiek}

By die Ou- en Nuwe-Testamentiese Wetenskap wil ons net die een saak aanroer, nl die plek en die aard van die hermeneutiek, aange- 
sien ander ensiklopediese probleme hier meer sake soos die korrekte benaming van onderindelings van die vakke raak.

Ons tyd is 'n tyd waarin die hermeneutiese vraag op teologiese gebied sterk op die voorgrond staan. Die hermeneutiese vraag het een van die belangrike teologiese vraagstukke op alle vakgebiede van die teologie geword. Daar is geen vakgebied wat kan sê dat dit onaangeraak gebly het deur die roeringe op hermeneutiese gebied nie. Die hermeneutiek is tradisioneel beskou as die vakgebied waarin gevra is na die reëls waarvolgens die Bybel uitgelê moet word. Die hermeneutiek het dan tot taak, die opstel van reëls vir die eksegese. In die jongste tyd het daar al hoe meer stemme begin opgaan en gaan daar nog steeds meer stemme op wat 'n nuwe en baie ruimer betekenis wil gee aan die begrip hermeneutiek (bv WS Vorster in: Eybers et al, 1978 $2: 89$ et seq). Die gedagte is dat die hermeneutiek nie slegs die reëls vir Bybeluitleg moet gee nie, maar hom moet besig hou met die vraag na die verstaan as sodanig. Dit wil ingaan op die vraag van die verstaanproses in die algemeen en op sigself. Dit wil vra: Hoe verstaan 'n mens enige gegewe teks en nie net alleen 'n Bybelteks in besonder nie? En eers wanneer die vraag na die totale verstaanproses beantwoord is, dan word van daaruit gevra: Hoe kan ' $n$ mens die histories-geworde teks van die Bybel vir mense in ons moderne tyd verstaanbaar maak en verstaanbaar uitlê? Hierdie opvatting van die hermeneutiek hou in dat dit 'n vak sal wees wat nie net tot die Bybel beperk bly nie, maar wat 'n interdissiplinêre vakgebied sal wees waarin filosofie, algemene literatuurwetenskap, kommunikasiekunde en ander geesteswetenskappe 'n beduidende sê het. Daar is dan ook 'n aandrang dat hermeneutiek in hierdie sin van die woord ' $n$ eie, onafhanklike en prominente plek onder die teologiese vakke moet inneem, selfs los van die $\mathrm{Ou}$ - en Nuwe-Testamentiese Wetenskap. Aan sommige universiteite is daar dan ook afsonderlike leerstoele in hermeneutiek ingestel.

Daar kan grondige besware ingebring word teen sommige aspekte van die nuwere siening oor die hermeneutiek as teologiese vak. Die eerste beswaar is dat hermeneutiek in dié sin van die woord dreig om 'n oorheersende en oorwoekerende plek onder die teologiese vakke in te neem en selfs in ' $n$ mate voorskrywend op te tree. In die tweede plek is daar die nie-onwesenlike gevaar dat die hermeneutiek aan die hand van 'n filosofiese leer oor die verstaansmoontlikhede van die mens ontwerp word, en dat ' $n$ bepaalde wysgerige denkpatroon dan die hermeneutiek en teologie bepaal. 
Hiermee hang ook nóú saam die gevaar dat 'n spesifieke teorie oorgeneem uit die algemene literatuurwetenskap en ook die metode wat daarmee saamgaan die inhoud van die hermeneutiek bepaal. Dan dreig die werklike gevaar dat die eksegese afhanklik gemaak word van 'n bloot teoretiese sisteem, wat dan ook die resultate van die eksegese bepaal in plaas daarvan dat die "teorie" homself voortdurend laat voed en korrigeer deur die Bybelteks waarmee gewerk word en die daadwerklike uitleg daarvan (H J Schilder in: Orientatie in de Theologie, $s$ a:64).

Al die kritiek ten spyt wil ons die vraag stel: Maak ons genoeg erns met die hermeneutiek in ons teologiese opleiding? Word daar 'n belangrik genoeg plek ingeruim vir hermeneutiek - veral op Ouen Nuwe-Testamentiese gebied? Dit is miskien ' $n$ oorskatting van die hermeneutiek om dit tot 'n onafhanklike dissipline te wil verhef, en ek is ook oortuig daarvan dat as ons van hermeneutiek wil praat ons dit nie heeltemal los kan maak van die tradisionele begrip van die woord nie, want wat die nuwe rigting in die hermeneutiek beoog, is tog iets anders; maar tog sal ons dan aan twee feite waarvoor die nuwe hermeneutiek ons stel, nie kan ontkom nie, dit is naamlik:

(1) Ons sal onsself moet verantwoord of ons die hermeneutiek werklik sy regmatige plek in die onderrig van Ou en Nuwe Testament gee, en (2) ons sal die nodige aandag moet gee aan die vraag na die verstaan van die Bybel en die verstaanbaar maak van die Bybelse boodskap vir die moderne mens. As dit 'n afsonderlike vakgebied moet wees, lyk dit nie of dit met reg hermeneutiek genoem kan word nie. Ek dink egter nie dat daar in die rigting van 'n enkele vak gedink moet word nie, maar veel eerder aan 'n gesamentlike poging en program van al die teologiese vakgebiede om die vraag na die verstaan en verstaanbaarmaking van die Bybel vir die moderne mens te beantwoord. En dit is 'n saak wat wyer gaan as die grense van die $\mathrm{Ou}$ - en Nuwe-Testamentiese Wetenskap (Heyns \& Jonker, 1974:283 et seq).

Aan ons fakulteit is tans ' $n$ hopelik belowende begin gemaak om 'n meer prominente plek aan hermeneutiek te gee. Die poging verloop op twee vlakke: 'n doseervlak en 'n studievlak. Op doseervlak word daar meer op seminaarvlak gewerk en is daar 'n klein komitee wat as begin ' $n$ reeks seminaarlesings aangebied het met as tema: van teks tot prediking. Op studievlak is daar ' $n$ interdepartementele studiegroep byeengeroep wat onder leiding van 'n sameroeper lede 
uit alle departemente van die fakulteit betrek by 'n studie van die hermeneutiek in sy toepassing op alle vakgebiede.

\subsection{Dogmatiek en Christelike Etiek}

\subsubsection{Simboliek}

By sommige teologiese fakulteite word daar ' $n$ afsonderlike plek ingeruim vir die vak Simboliek, soos byvoorbeeld die Gereformeerde Kerk. Simboliek is dan die vak wat hom besig hou met die studie van die verskillende kerklike belydenisskrifte (simbole) en dan met die vorm van die kerklike dogma soos dit in die verskillende belydenisskrifte skriftelike neerslag gevind het. By ons fakulteit beklee dit nie ' $n$ afsonderlike plek nie, maar word dit ingeweef in die aanbieding van die vak Dogmatiek. Ons sou nie wou pleit vir 'n afsonderlike vak Simboliek nie, maar is tog van oortuiging dat, behalwe vir die drie formuliere van eenheid, daar hoogstens ' $n$ vae en baie onduidelike kennis van ander simbole by die gemiddelde student tuiskom. Daar behoort minstens in die dosering van die Dogmatiek, ' $n$ poging aangewend te word om ook ander simbole binne die gesigskring te bring. 'n Ander oplossing kan wees dat die Dogmatiek en die Dogmengeskiedenis 'n plan van samewerking kan opstel om gesamentlik meer aandag aan die simboliek te gee.

\subsubsection{Polemiek}

Predikante wat in die praktyk van die bediening staan, het al meermale die stelling gemaak dat hulle met ' $n$ minimum van kennis van sektariese leerstellinge en afwykende opvattinge oor die Christelike leer, wat in die gewone gang van die lewe teengekom word, die gemeente moes binnegaan. Daar word dan gevra dat groter aandag aan die saak gegee moet word. Een oplossing sou wees om die vak polemiek, as afsonderlike vak in te voer (as ons Kuyper se terme wil gebruik). Tog is dit 'n vraag of dit werklik geregverdig is om 'n afsonderlike vak net hiervoor af te sonder. Ek is van mening dat ' $n$ afsonderlike vak nie nodig is nie, aangesien die Dogmatiek so beoefen moet word dat die bestryding en weerlegging van die verkeerde leer en dwalinge, gegrond op valse argumente, 'n onontwykbare onderdeel van die Dogmatiek moet wees. 'n Mens kan wel oorweeg of daar nie in die selfstudie aandag gegee kan word aan die sektewese, die strydgesprek met Rome, ens nie. 


\subsubsection{Ekumeniese Teologie}

Onder Ekumeniese Teologie word iets anders verstaan as wat die studiegebied Ekumeniese Studies (of Ekumeniek) behels. Ekumeniese Studies maak 'n studie van die vraagstuk van die eenheid en verdeeldheid van die kerk vanuit 'n kerkhistoriese en kerkordelike gesigspunt en hoort tuis onder die kerkhistoriese vakke. Ekumeniese Teologie het iets anders op die oog. Volgens een van die belangrike woordvoerders van die Ekumeniese Teologie, A König (Eybers et al, 1978'2:297 et seq), vra die Ekumeniese Teologie (in die wydste sin van die woord) na die korrekte verhouding tussen die verskillende konfessies, en veral na die moontlikheid dat die verskillende konfessies die openbaring saam kan bely, bestudeer en verstaan. Onder konfessie word dan meer verstaan as net die belydenis, dit sien veral op die breë geheel van die teologie van 'n konfessionele groep. Die Ekumeniese Teologie veronderstel dan ook meer as net dat dit 'n verhouding tussen konfessies wil aandui of dat dit 'n metode wil wees waarop konfessies mekaar kan leer ken en beter begryp. Dit moet veral gesien word as 'n metode waarvolgens alle konfessies saam die Skrif as openbaringsgetuienis kan bestudeer. Uiteindelik moet die Ekumeniese Teologie nie net beperk bly tot die Dogmatiek nie, maar moet dit 'n struktuurelement in die teologiese metode word, sodat teologie, in al sy dissiplines, nie meer binne die grense van 'n bepaalde konfessie beoefen word nie, maar gesamentlik binne die ruimte van die een openbaring betuig in die Bybel.

Die Ekumeniese Teologie (soos ons dit by König vind) rus op sekere grondgedagtes. Die eerste is 'n vereenselwiging met sekere basiese gedagtes van die wêreldwye ekumeniese strewe. Hiermee saam hang die aanvaarding dat alle verdeeldheid van die kerk sondig en in stryd is met die wesenlike gegewe eenheid van die kerk in Jesus Christus. Die volgende veronderstelling is dat daar alleen vanuit die eenheid van die kerk gedink moet word en dat dit inhou dat die ganse geloof van die kerk, en die ganse Skrifboodskap vanuit die grondbegrip van die eenheid van die kerk deurdink moet word. Nog 'n baie belangrike veronderstelling is dat die volle waarheid aan die hele kerk gebonde is en nie binne die eng konfessionele grense bereik kan word nie. Eenheid en waarheid staan nie teenoor mekaar nie, maar eenheid is ' $n$ wesenlike faset van die waarheid omdat die kerk vanselfsprekend een is. König beklemtoon die saak so sterk dat hy selfs in die rigting dink dat elke belydenis en dogma namens die 
hele kerk gedoen moet word en dat dit 'n vraag is of afgeskeurde dele van die één kerk werklik kan bely (Eybers et al, 1978²:147).

In die lig van die veronderstellings is dit vir hom duidelik dat die kerk hom dit ten doel moet stel "om sy studente wetenskaplik te laat vorm aan 'n ekumeniese fakulteit waarin daar ook onderlinge bevrugting en stimulering plaasvind en waar studente onder die indruk kom van die opdrag tot Christelike eenheid en die sondigheid van kerklike verdeeldheid" (Eybers et al, 1978²:327).

Dit is dan ook volgens sy mening ' $n$ toestand van sake wat nie te rym is waar daar meer as een teologiese fakulteit ( $\mathrm{nl}$ van verskillende kerke) aan dieselfde universiteit bestaan nie (Eybers et al, 1978²:326). Ons moet oop genoeg wees om net een fakulteit vir meer as een kerk te aanvaar.

Daar kan baie besware teen so 'n opvatting van Ekumeniese Teologie ingebring word, o a dat die beoefening van teologie sonder kerklike gebondenheid neerkom op 'n swewende, oewerlose en fondamentlose beoefening van teologie, ' $n$ teologie wat nie 'n vaste basis het van waaruit oordele gevel kan word nie. Tog stel die Ekumeniese Teologie sekere wettige vrae aan ons, naamlik eerstens:

Maak ons aan ons fakulteit die nodige erns met die vraagstuk van die verdeeldheid en die eenheid van die kerk in die werklike onderrig van die studente en die leerstof wat aan hulle voorgeskryf word?

Tweedens: Laat ons in ons beoefening van die teologie die nodige ruimte om ons eie standpunt te laat korrigeer deur die standpunte van ander konfessies? Met ander woorde beoefen ons nie dalk teologie in selftevrede isolasie nie, en moet ons nie meer geleentheid gee om kennis te neem van wat ander standpunte sê nie? Om erns te maak met die saak is daar twee moontlikhede: ' $n$ mens kan 'n afsonderlike vakindeling oorweeg waarin aandag gegee word aan die sake wat deur die Ekumeniese Teologie op die voorgrond gebring is, (natuurlik gevorm na ons eie opvatting). Die tweede moontlikheid, wat $\mathrm{m}$ i miskien die beste is, is dat elke afsonderlike vakgebied hieraan sal aandag gee en met die klem op die eie standpunt, dit in die leerstof inwerk.

\subsubsection{Christelike etiek}

Dit is Karl Barth wat met groot oortuiging die standpunt gestel het dat daar so 'n onlosmaaklike band tussen Dogmatiek en Christelike Etiek is, dat hy 'n etiek daar wil stel wat as 't ware 'n onderdeel van 
die Dogmatiek is en in verweefdheid met die Dogmatiek uit die Dogmatiek voortvloei. Die sterk waarheidselement van hierdie gedagte is dat leer en lewe nou saamhang. Die Christelike leefwyse groei op die bodem van die leerstellige oortuiginge en elke etiek veronderstel 'n sekere teologiese onderbou. Dit kan nie ontken word nie. Die vraag is net kan ons vandag nog in die praktyk etiek op die manier beoefen? Is ' $n$ siening soos Barth s'n nie in ons dag in 'n sekere sin maar 'n geïdealiseerde siening nie? Moet die Christelike Etiek nie 'n selfstandigheid los van die Dogmatiek verkry nie?

In die reformatoriese kringe het sake so verloop dat in Calvyn se tyd etiese vrae bloot ' $n$ onderdeel van dogmatiese handboeke gevorm het. Dit het egter gaandeweg duidelik geword dat Etiek nie maar net meer as 'n onderdeel van die Dogmatiek beskou kan word nie en al hoe meer afsonderlike etiese werke het verskyn. In ons dag het die kompleks van etiese vrae so uitgebreid geword en vra dit sulke indringende aandag dat 'n afsonderlike behandeling van etiese vrae in werklikheid noodsaaklik geword het. Dit is vandag dan ook eerder die reël as die uitsondering dat daar 'n afsonderlike leerstoel in Christelike of Teologiese Etiek aan 'n teologiese fakulteit is.

Hoewel die band met die Dogmatiek en die belydenis nie verbreek kan word nie, lyk dit vir my asof ons 'n groter selfstandigheid van die Etiek sal moet aanvaar. Ons lewe in 'n tyd waarin bykans alles tot 'n "moral issue" verhef word, en ons sal die antwoorde moet verskaf.

Die groter selfstandigheid van die Christelike Etiek is nie sonder probleme nie. 'n Belangrike probleem lê rondom die begrip etiek. Etiek is nie vanselfsprekend 'n teologiese vak nie. Daar is verskillende vorme van filosofiese Etiek. Selfs die voorvoegsel "Christelik" maak dit nog nie 'n teologiese vak nie. Dit kan maklik 'n etiek wees wat vanuit 'n Christelik gekleurde filosofie beoefen word. Eers wanneer die Etiek vra na die etiese implikasie van God se Woord en gebooie, soos dit onder andere ook verwoord is in dogma en belydenis, met God se Woord as eerste, laaste en bindende norm, word dit 'n Teologiese Etiek. Daar is dus altyd die gevaar dat die Christelike Etiek kan verskraal tot 'n blote filosofiese Etiek.

Al die gevare ten spyt lyk dit vir my sinvol om te dink in die rigting van 'n groter prominensie en selfstandigheid van die Christelike Etiek. 'n Mens kry te dikwels die indruk dat Etiek maar net as 'n soort lastige byvoegsel, 'n los aanhangsel, 'n "stopvak" deur 
studente aan ons fakulteit ervaar en beskou word, en dat die volle belang en plek daarvan nie behoorlik deurdring nie. Daar is egter ook bemoedigende tekens soos die feit dat een van die predikante van ons kerk sy doktorsgraad in die Christelike Etiek verwerf het en dat daar ook al meer studente is wat 'n onderwerp uit die vakgebied van die Etiek vir hulle BD-skripsie kies.

'n Selfstandige departement van Christelike Etiek kan op die stadium vanweë praktiese redes miskien nie oorweeg word nie, maar die moontlikheid kan wel seker vir die toekoms oorweeg word. Die mees praktiese oplossing sal seker wees om aan Christelike Etiek 'n meer selfstandige plek te gee binne die omraming van die afdeling Dogmatiek en Christelike Etiek.

\subsection{Geskiedenis van die Christendom}

\subsubsection{Dogmengeskiedenis}

Dogmengeskiedenis is ' $n$ vak wat raakvlakke het met die Kerkgeskiedenis en Dogmatiek. Daarom is dit moontlik om die vak saam met Kerkgeskiedenis te groepeer (soos by ons) of saam met Dogmatiek (soos by die Gereformeerde Kerk). Dogmengeskiedenis hou hom besig met die studie van die probleem van die leerstellinge, veranderinge en die ontwikkeling van die kerklike dogmas in die loop van die kerkgeskiedenis. Dit is so dat die metodes en uitgangspunte van die Dogmengeskiedenis vir die grootste gedeelte histories is en dit dus ' $n$ historiese wetenskap is wat in noue samehang met die Kerkgeskiedenis bestaan. Vanuit die hoek gesien kan ' $n$ mens stel dat Dogmengeskiedenis by kerkgeskiedenis tuis hoort.

Aan die ander kant werk die Dogmengeskiedenis met die kerklike dogma. Die dogma is die voorwerp van studie. Daar is ' $n$ sekere verband en oorvleueling tussen Dogmengeskiedenis en Dogmatiek. Ons kan ook sê dat daar 'n sekere gerigtheid is van die Dogmengeskiedenis op die Dogmatiek en omgekeerd. Die Dogmengeskiedenis wil vanuit die verlede heenwys na die Dogmatiek om die Dogmatiek in staat te stel om die dogma helderder te interpreteer, maar die Dogmatiek is van sy kant af ook weer genoodsaak om terug te gryp op die Dogmangeskiedenis in sy uiteensetting van die dogmas. Vanuit die gesigspunt gesien behoort die Dogmengeskiedenis tuis by die Dogmatiek.

Ek is daarvan oortuig dat dit in die praktyk so is dat die Dogmen- 
geskiedenis so effens in 'n lugleegte hang in ons fakulteit. 'n Mens kry die indruk dat Dogmengeskiedenis nie tot vrugbare en toepasbare kennis deur die studente verwerk word nie. Ek is oortuig daarvan dat die oorsaak daarin geleë is dat Dogmengeskiedenis bloot as historiese vak benader word en daar nie ' $n$ konkrete band met die Dogmatiek gelê word nie. 'n Mens sou aan die hand kon doen dat Dogmengeskiedenis verskuif word na 'n onderafdeling van Dogmatiek (hoewel dit ook sy probleme het). 'n Prakties werkbare voorstel binne die huidige indeling is dat daar nouer skakeling en samewerking tussen die departemente Dogmatiek en Christelike Etiek en Geskiedenis van die Christendom sal kom om te probeer om ooreenstemmende en aanvullende stof in ' $n$ betrokke studiejaar aan te bied, byvoorbeeld, in die jaar waarin die Christologie in die Dogmatiek behandel word, spits die Dogmengeskiedenis hom toe op die ontwikkeling van die Christologiese dogma.

\subsubsection{Kerkreg (ook: Kybernetiek)}

Kerkreg vra na die grondbeginsels wat geld vir die inrigting en orde van die kerk volgens God se Woord. Dit vra na die konstituerende reg vir die kerk as instituut, soos God dit gewil het. Daar kan vanuit drie teologiese vakgebiede aanspraak gemaak word op die reg om die Kerkreg onder hulle vleuels te neem, en dan kom daar nog elemente van ' $n$ nie-teologiese vakgebied ook by. Eerstens kan Kerkreg saam met Kerkgeskiedenis gegroepeer word, want enige kerkreg is verplig om die geskiedenis van die ontwikkeling van die kerkregering na te gaan en te beskryf en krities aandag te gee aan die verskillende vorme van kerkregering wat deur die eeue ontwikkel het. Dit vorm 'n onontbeerlike element van die Kerkreg. Tweedens kan kerkreg ook saam met Dogmatiek gegroepeer word, want die Kerkreg hou hom ook besig met dogmaties-eksegetiese vrae soos: Wat is die wese van die kerk, wat beteken begrippe soos die sigbare en onsigbare kerk, wat beteken dit dat Christus hoof van sy kerk is, wat is ' $n$ amp, ens? Dit is miskien hier die plek om daarop te wys dat daar ook 'n sterk regsaspek aan Kerkreg verbonde is, en dat Kerkreg vir 'n lang tyd tot met die Tweede Wêreldoorlog 'n hoofvak aan die regsfakulteite van Duitse universiteite was. In die jongste tyd kom daar uit die rigting van die Praktiese Teologie ook 'n aanspraak op Kerkreg. Die gedagte is dat Kerkreg hom ook besig hou met die praktiese organisasie van die kerk en die heersende kerkreg soos dit 
uit ander reëlings van die kerk in die praktyk voorkom. Dit gaan dus ook om die praktiese toepassing van die kerkreg. Kerkreg sou dan gekoppel kon word aan 'n vakgebied binne die Praktiese Teologie wat deur sommiges kybernetiek genoem word, di die teorie vir die bestuur van die gemeente na organisatoriese sowel as materiële kant.

As ons die historiese aspek van Kerkreg sowel as die dogmatieseksegetiese aspek (wat weer op gegewens uit die Dogmengeskiedenis sal moet aanleuen) let, lyk dit vir my asof die departement Kerkgeskiedenis die grootste aanspraak op die vak Kerkreg het. Dit lyk asof daar van die kant van die Praktiese Teologie te veel klem gelê word op die praktiese aspek (sien 2.4. hieronder). 'n Verskuiwing van Kerkreg is dus nie nodig nie. Waaraan wel aandag gegee kan word, is dat daar nouer skakeling sal kom tussen die professor in Kerkgeskiedenis en die professor in Praktiese Teologie vir 'n koördinering van leerplanne.

As afsluitende gedagte wil ons daarop wys dat daar in ons dag twyfel na vore gebring word oor die bestaansreg van Kerkreg. Twee gedagtes lê hieragter: Die besef van verandering van strukture en revolusionêre vernuwing wat op sommige teoloë beslag gelê het, maak die kerklike organisasie verdag. Verder word gestel dat die klem op die kerk as instituut 'n gebrek aan solidariteit tussen die kerk en die probleme van die mensdom tot gevolg het.

\subsection{Praktiese Teologie}

Daar is al gestel dat die naam Praktiese Teologie miskien 'n ongelukkige keuse is. Een van die gevolge van die naam is dat ' $n$ mens mislei kan word om op imperialistiese wyse alle vakgebiede wat met die praktyk te doen het, te wil opslurp en onder Praktiese Teologie tuis te bring. Sodanige probleemgebiede wat die Praktiese Teologie raak, kom onder punte 2.3.2 en 2.5.1 onder bespreking. Ander benaminge wat vir Praktiese Teologie voorgestel is en gebruik word, is: die diakonologiese vakke of amptelike vakke.

Nog 'n saak waaraan aandag gegee sal moet word, is die nuwere gedagterigtings dat die Praktiese Teologie hom nie net kan beperk tot die teologiese nie, maar in al groter mate sal moet integreer met die nie-teologiese handelingswetenskappe. 


\subsection{Godsdienswetenskap en Sendingwetenskap}

Ons wil by hierdie vakgebied slegs ingaan op die plek van Evangelistiek.

\subsubsection{Evangelistiek}

Evangelistiek is die vak wat hom besig hou met die studie van die probleme rondom die verkondiging van die evangelie aan en die getuienis van die kerk teenoor die buite-kerklike mens, di die mens wat nie meer lidmaat is van die kerk nie, maar tog op een of ander stadium of wyse ' $n$ band met die kerk gehad het. Daar is twee moontlikhede om die vak in te deel: by Sendingwetenskap of by Praktiese Teologie. Die argument van prakties-teologiese kant is dat ons hier te doen het met 'n vak wat homself besig hou met die praktiese metodes en werkwyse om die evangelie aan buite-kerklikes te bring. Van Sendingwetenskaplike kant kan die saak so gestel word: Die kerk het sy ontstaan en groei aan die oorspronklike sendingaksie van die vroegste kerk te danke, 'n proses wat vandag nog voortgaan onder heidense volke. Waar daar vandag ' $n$ afval van die kerk wat by sy ontstaan deur 'n sendingaksie tot stand gekom het, plaasvind, is die logiese aansluitingspunt vir die Evangelistiek die Sendingwetenskap. Evangelistiek sluit aan en vloei logies voort uit die Sendingwetenskap. Dit is 'n erkende feit dat die grense tussen evangelisasie en Sendingwetenskap maar baie vaag en vloeibaar is. In die toekoms, met toenemende ontkerkliking, sal dit steeds vaer word. Daarby kom ook dat die gemiddelde student Sendingwetenskap maar as 'n baie vae en teoretiese vak ervaar wat hy nie kan deurtrek na sy werk in die gemeente nie. Deur Sendingwetenskap en Evangelistiek naas mekaar te groepeer vind die dikwels teoretiese studie van die Sendingwetenskap in die Evangelistiek 'n logiese, konkrete en bruikbare vastrapplek en kan die studie vrugbaarder in die gemeentelike lewe gebruik word.

Hierdie argumente van sendingwetenskaplike kant maak in elk geval een saak duidelik en dit is dat waar'n mens Evangelistiek ook inorden, al sou dit dan ook by Praktiese Teologie wees, dan sal die band met die Sendingwetenskap nie losgelaat kan word nie sodat die sendinggerigte perspektief nie dalk verlore gaan nie.

Soos sake tans staan is Evangelistiek aan ons fakulteit hoofsaaklik die verantwoordelikheid van die departement Praktiese Teologie. Uit 'n gesprek met prof $P \mathrm{~J}$ van der Merwe het dit geblyk dat o a die volgende argumente ' $n$ rol gespeel het by die huidige werksverde- 
ling aan die fakulteit wat Evangelistiek betref: Ons het in SuidAfrika nog nie heeltemal die Europese opset bereik waar a $g$ v grootskaalse ontkerkliking die grense tussen Sendingwetenskap en Evangelistiek vervaag het nie. Anders as in Europa het ons nog 'n duidelik aanduibare teikengroep vir die sending van mense wat uit 'n nie-Christelike en heidense agtergrond kom. Daarenteen is die situasie met evangelisasie tans nog so dat dit hoofsaaklik gerig is op mense wat redelik onlangs eers ingetrek is by die proses van ontkerkliking en sekularisasie en dus grotendeels op binne-gemeentelike en gemeentegebonde vlak verloop - 'n vlak wat hoofsaaklik raakpunte het met die terrein van die Praktiese Teologie. Versnelde sekularisasie en ontkerkliking kan omstandighede heeltemal verander sodat Evangelistiek en Sendingwetenskap nader aanmekaar mag beweeg, maar soos die situasie tans is, lyk dit sinvol om Evangelistiek hoofsaaklik die verantwoordelikheid van Praktiese Teologie te maak.

Daar is na oorleg tussen die twee Departemente van Sendingwetenskap en Praktiese Teologie besluit om 'n pragmatiese benadering te volg in die aanbieding van Evangelistiek. Daar is eerstens besluit dat Praktiese Teologie die hoofverantwoordelikheid sal hê vir die aanbieding van Evangelistiek. Daar is ook besluit om 'n interdepartementele studiegroep in die lewe te roep waar die twee departemente saam besig kan wees met navorsing oor Evangelistiek met die bygedagte dat so ook sorg gedra sal word dat die missionêre dimensie nie uit die oog verloor sal word nie.

Op doseervlak neem die Departement Praktiese Teologie die verantwoordelikheid vir die aanbieding van Evangelistiek en gee ook die grootste deel van die lesings. Die Departement Sendingwetenskap bied wel ook 'n kleiner deel van die lesings aan. Die lesings is lesings wat meer gerig is op die makro-sosiale, ideologiese en godsdiensverskynsels wat saamhang met ontkerkliking en sekularisasie. Dit is lesings wat meer moet dien as 'n omraming en agtergrond vir die aanbieding van die vak Evangelistiek self, wat die verantwoordelikheid van Praktiese Teologie is. Daar is ook 'n afspraak dat daar 'n gereelde skakeling tussen die twee departemente sal wees om die inhoud van die modules te bepaal wat deur die Departement Sendingwetenskap aangebied sal word.

Aan die hand van die voorbeeld van samewerking tussen bogenoemde twee departement, maar ook in die lig van die gevolgtrekkings wat ons gemaak het oor die plek en samehang van die teolo- 
giese vakke by die ander departemente van ons fakulteit, het ek tot die gevolgtrekking gekom dat ons in die toekoms nie meer sal kan volstaan by 'n strakke en heeltemal vaste indeling van die teologiese vakke nie. Die vakindelinge soos ons dit tans het, is die erfenis van 'n historiese proses van spesialisasie. In die toekoms sal ons bereid moet wees om 'n funksioneel-pragmatiese houding in te neem t o v vakindelinge. Ons sal bereid moet wees om verskuiwings in vakke te maak of wisselwerking tussen departemente t o $\mathrm{v}$ sekere vakke tot stand te bring. Ons sal meer oor die mure van spesialisasie heen moet beweeg om kennis te neem van wat mense op ander vakgebiede van die Teologie sê om so ook weer ons eie vak vanuit die oogpunt van die Teologie as geheel te sien. Ons moet bereid wees tot voortdurende gedagtewisseling en wisselwerking.

Ons sal by alles wat ons hierbo gesê het voortdurend die praktiese opleidingsituasie in ag moet neem om ons vakindelings en vakaanbiedinge so te skik dat dit die bearbeidingsbehoefte van die kerk ook die beste sal pas. So sal die belang van die kerk ook die beste gedien word.

\section{Literatuurlys}

Eybers, I H e a. Inleiding in die Teologie. Pretoria, $1978^{2}$.

Ganzevoort, B W Inleiding in de Theologie. Kampen, 1955.

Heyns, J H \& W D Jonker. Op weg met die Teologie. 1974.

Koekemoer, J H. Die verhouding van Kerk-en Dogmengeskiedenis. Klasreferaat, s a.

Kuyper, A. Encyclopaedie der Heilige Godgeleerdheid. Kampen, 1908².

Orientatie in de Theologie. Studiegids samengesteld door de hoogleraren aan de Theologische Hogeschool van de Gereformeerde Kerken in Nederland te Kampen, Deventer, s a. 